\title{
AGORA QUERO CANTAR A FRAGMENTAÇÃO DA PLENITUDE
}

\author{
(Aos 100 anos de Mário de Andrade) \\ Lauro Junkes* \\ Universidade Federal de Santa Catarina
}

\section{Introdução}

No meu ensaio A Fragmentação da Plenitude, defendido e aprovado no Concurso para Professor Titular de Teoria da Literatura na Universidade Federal de Santa Catarina em 1992, explanei o conceito clássico-romântico de símbolo e alegoria, sobretudo em Schelling, Hegel e Goethe, para, com mais detalhes, aprofundar a alegoria como expressão da modernidade em Walter Benjamin. O ensaio culminava com a aplicação prática desses conceitos-figuras à poesia de Mário de Andrade (dois centenários sucessivos).

Por inviabilidade de espaço neste gênero de publicação, omitiu-se uma centena e meia de páginas em torno dos conceitos teóricos de alegoria e símbolo, privilegiando a análise do poema de Mário, perfeitamente compreensível sem todos os pormenores daquele suporte teórico.

Se a alegoria é, por vezes, apontada como a marca da Modernidade — linha de certo modo subjacente ao pensamento do próprio Walter Benjamin, de Peter Burger e mesmo de Erika Fischer-Lichte, entre outros - pergunta-se se em Mário de Andrade se confirma tal

EY No ND Esta obra está licenciada sob uma Licença Creative Commons.

\footnotetext{
* Doutor em Linguística e Letras pela Pontifícia Universidade Católica do Rio Grande do Sul (1993). Foi professor titular da Universidade Federal de Santa Catarina até 2005, quando se aposentou. Também foi Professor Voluntário no Programa de Pós-Graduação em Literatura, com experiência na área de Letras, com ênfase em Literatura Catarinense, atuando principalmente na área de literatura catarinense: poesia, história literária, crítica literária. Foi presidente da Academia Catarinense de Letras: 2003-2004; 2004-2006; 2006-2008; 2008-2010.
} 
hipótese. Evidentemente não pretenderá este ensaio aplicado - concentrando-se no longo poema-estória "Agora quero cantar", incluído no livro Lira Paulistana - esgotar a questão, nem examinar exaustivamente a poesia do mestre do Modernismo brasileiro.

Esse livro da fase final do poeta mantém uma certa relação com Paulicéia Desvairada, da fase inicial. Ambos enfocam o poeta, quase que um flâneur baudelaireano, um observador curioso perambulando pela cidade de São Paulo, muito às voltas com o transitório, efêmero e contingente. Mas, a euforia e a própria criatividade verbal do primeiro, o estado arlequinal - para Benedito Nunes (1984, p. 67), Arlequinal é o adjetivo desse estado de marginalização declarado do poeta, que, desvairado, só pode introduzir-se na cidade alucinada pelo disfarce de Arlequim-palhaço-louco — passam agora pela amarga revisão apontada por Lafeta (1980). Mário, ainda a semelhança de Baudelaire, retrata mais vivamente a engrenagem industrial da cidade, o indivíduo massificado no social, a ênfase na figura marginal, a pessoa quase reificada, mais objeto que sujeito. Se outras vezes Mário assumira facetas de "dândi", aqui ele como que veste a camisa contrária. Também a Baudelaire, Mário manifesta sua revolta contra a "alma desprezível" da burguesia (observe-se "Mora linda bem tratada"). O observador incógnito na massa social, com a sensação baudelairiana da solidão na multidão está drasticamente caracterizado no curto poema "O bonde abre a viagem", contrastando/revigorando o poeta literalmente só: "Estou só, estou sem" com o poeta na multidão:

\footnotetext{
O bonde está cheio,

De novo porém

Não sou mais ninguém.
}

(Note-se o sujeito estilhaçado, fragmentado, descontextualizado — bem na linha benjamineana do processo de alegorização).

Como seria extremamente longo analisar todos os poemas desse conjunto, este trabalho centraliza-se no poema-estória "Agora eu quero cantar". Trata-se aparentemente de simples versos de um "cantador" popular, mas que o "poeta político" reveste de todo um dramático senso social. Compõe-se o poema de quatro partes ou segmentos, construídos de forma simétrica, sobretudo pelo seu final, e que correspondem a diferentes fases da "vida" do "herói", ainda na esteira baudelairiana de destacar a heroicidade da vida privada.

Cada segmento se compõe de quatro estrofes. Após essas partes, há um final ou epílogo, formalmente bem destacado. 


\section{Análise do poema "Agora quero cantar"}

O primeiro segmento contém a proposição do assunto, quase de forma épica, e retrata a seguir o nascimento e a infância do "herói" Pedro.

Agora eu quero cantar Uma história muito triste Que nunca ninguém cantou, A triste história de Pedro, Que acabou qual principiou.

Não houve acalanto. Apenas Um guincho fraco no quarto Alugado. O pai falou, Enquanto a mãe se limpava: - É Pedro. E Pedro ficou.

Ela tinha o que fazer, Ele inda mais, e outro nome Ali ninguém procurou, Não pensaram em Alcibíades, Floriscópio, Ciro, Adrasto, Que-dê tempo pra inventar! —É Pedro. E Pedro ficou.

Pedrinho engatinhou logo Mas muito tarde falou; Ninguém falava com ele, Quando chorava era surra E aprendeu a emudecer. Falou tarde, brincou pouco, Em breve a mãe ajudou. Nesse trabalho insuspeito Passou o dia, e nem bem A noite escura chegou, Como única resposta Um sono bruto o prostrou.

Por trás do quarto alugado Tinha uma serra muito alta Que Pedro nunca notou, Mas num dia desses, não Se sabe por quê, Pedrinho Para a serra se voltou: - Havia de ter, decerto, Uma vida bem mais linda Por trás da serra, pensou.

O primeiro verso marca início típico do processo do "cantador", como se fosse iniciada uma história (ou estória) dessas que se narra ou "canta" por passatempo, para divertir e ocupar prazerosamente a atenção dos ouvintes. Mas, será "uma história muito triste", indiciando o elemento ou a finalidade sentimental, que geralmente se manifesta bem saliente nesse tipo de poema história. E o simples tom sentimental do "triste" não é apenas reforçado, mas recebe uma carga trágica, realisticamente trágica, no último verso dessa estrofeproposição, pela inversão dos verbos em relação aos fatos, da enunciação em relação à 
diegese: "Que acabou qual principiou". A correspondência sonora das rimas internas em eco, ou melhor, leoninas, ao mesmo tempo que enfatiza a ligação semântica entre as duas palavras, em sentido antitético, destaca a importância das mesmas, por nelas recair o acento cadencial. Entretanto, a ordem lógica desses verbos seria a inversa, pois é preciso primeiro principiar para depois acabar. A inversão, iniciando por "acabou", revela a drástica intenção social do poeta em acentuar a fase ou a tonalidade trágica dessa história ou da "vida" da personagem. Como se quisesse sugerir que a história de Pedro "acabou" antes de principiar, ou melhor, não a "história", mas a "vida" - isto é, Pedro foi de tal modo jogado no mundo e tateou por ele, como se de fato não tivesse "vivido", não atingiu o nível de vida de um autêntico ser humano, racional, inteligente, sensível. ( $\mathrm{O}$ fragmentário frustrado se impõe a qualquer equilíbrio harmonioso).

A estrofe que principia a narração da vida de Pedro vem iniciada por uma longa negação, o que representa outra violência em relação ao substantivo "acalanto", carregado de mimo e ternura. A recepção de Pedro na vida já foi sem ternura amorosa, sem carinho que atenuasse o choque do nascimento e da vida. Essa ausência de ternura e carinho, que existe mesmo entre os animais em relação aos filhotes, vem reforçada pelo substantivo "guincho", esse som agudo e inarticulado, mais próprio do animal do que do homem. A entrada de Pedro no mundo está, pois, quase abaixo do puro nascimento animal.

Observe-se também que, paralelamente a esse canto nada poetic ${ }^{\circ}$, a forma versificada e apenas uma convenção quase violentadora do fluxo normal da sintaxe. Em lugar da linha partida, a escrita corrente se apresentaria ate melhor na aparência: "Não houve acalanto. Apenas um guincho fraco no quarto alugado. O pai falou, enquanto a mãe se limpava..." Pedro e uma figura por demais prosaica, destituída de qualquer qualidade que merecesse maior preocupação formal, alguém a margem da consideração social e da condição humana. A partição do fluxo sintático em redondilhas maiores parece simples convenção apropriada ao interesse do cantador. Tudo isso, no entanto, é habilidade do poeta.

Toda a ambientação criada nesta estrofe mantém adequação perfeita com o assunto e o tom de tratamento. O cenário é um "quarto/alugado", acentuando esse enjambement a condição de carência. As atitudes do pai e de mãe o confirmam plenamente. A mãe é sua própria parteira, caracterizada com crueza naturalista: "enquanto a mãe se limpava..." Ela tinha muito que fazer, ao contrário do repouso indispensável à parturiente. E o pai igualmente. Daí a displicência em relação ao nome para o filho. Por que preocupar-se com nomes altissonantes, se a vida é vazia? Eles próprios aparecem anônimos. E por que "Pedro"? 
Aparentemente por motivo algum, possivelmente por ser nome popular e comum. Mas "Pedro" pode remeter - carregado de ambiguidade - para um nome celebrado, um nome bíblico: o Pedro que, ambígua e contraditoriamente, renegou três vezes o seu Mestre Jesus na situação mais difícil deste e, assim mesmo, foi estabelecido como Chefe da nova comunidade cristã, segundo a tradição também "crucificado" em defesa da sua crença; "Pedro" que tem seu étimo em "pedra", ainda ambiguamente conotando dureza, insensibilidade, mas por outro lado constituindo o fundamento seguro (da construção arquitetônica, da comunidade eclesial). Os outros nomes - esdrúxulos ou célebres - não devem ser cogitados, mas são tão vazios como Pedro.

A linguagem empregada, correspondentemente, é direta e corrente, sem enfeites nem figuras. Apenas algumas antíteses podem estar implícitas. Assim "cantar" (= alegria, expansividade) no contexto renega sua conotação fundamental, o que vem reforçado quando o verbo (em dois finais de verso) se contrapõe ao adjetivo "triste" (em outro final de verso). A antítese, na expressiva inversão, "acabou/principiou" já foi comentada. Também o "acalanto", negado pelo advérbio, pode relacionar-se (normalmente acompanhado da suavidade terna da canção de ninar) antiteticamente ao realista e quase animal "guincho". O verbo "inventar" pode ainda ser visto como uma possível antítese. Se "existe" o nome Pedro, se a realidade nua e crua ali está e se impõe, por que "inventar" nomes ou por que sonhar com utopias ilusórias? Essas antíteses portanto apresentam forte orientação realista, desilusória, opressora, na tendência social do poema (na linha benjamineana da "história": frustração, ruína, morte, caveira).

A estrofe seguinte deixa transparecer a educação repressora e carente, ao nível da carência geral dessa classe social baixa. $O$ ato simplesmente físico e instintivo "engatinhou" — processou-se normalmente. Mas o ato intelectual — "falou" — ficou duplamente prejudicado: pela repressão, pois a manifestação "sonora" era emudecida pela surra, e pela ausência de estímulo com quem falar. Se o mundo da criança já é restrito, Pedrocriança sofreu maiores restrições: as atividades normais de falar e brincar foram podadas. Mas sempre ambiguamente, o poeta-cantador acrescenta que "em breve a mãe ajudou", o que de certo modo desfaz a restrição-repressão. E tudo passa a ser caracterizado como "trabalho insuspeito". Pergunta-se: como "trabalho"? Não existe lazer, brincadeira, pura distração para certas camadas sociais? Mais estranho ainda se insinua o adjetivo "insuspeito". A atividade de certas pessoas, de certas camadas sociais, é sempre suspeita, perigosa ao sistema estabelecido? 
Agora é preciso destacar como, na linha social opressora desilusória, a estrutura do poema vai jogar com palavras que apontam para muito além do seu sentido próprio. Assim temos os conjuntos opostos "dia-trabalho" x "noite-sono", que sempre se associam com a percepção da "serra", interposição drástica entre o aqui-e-agora e o possível além. A referencia a palavra "dia" ocorre sempre associada ao trabalho, a dificuldade, a luta pela sobrevivência (que seria melhor caracterizada como sub-vivência) e não designa simplesmente o período temporal determinado pelo giro do sol, ou melhor, da terra, mas indica toda uma fase, um período, algo determinante na "vida" da personagem. Esse "dia", por outro lado, metonímia ou sinédoque, em que "parte" temporal menor indica um certo "todo" maior e, por outro lado, pode conter indicador metafórico, relacionando "dia" com "vida". Isso em oposição a "noite", igualmente metonímica em relação ao período temporal que abrange e metafórica pela conotação com a ausência de vida, a morte.

O "dia" se relaciona com o "trabalho", e ocupado por este. O trabalho é atividade fatigante, um autêntico "castigo", nada agradável, muito menos compensador. Por isso, ao dia/trabalho sucede a noite/sono. Nesse primeiro segmento, caracteriza-se não em simples pleonasmo a "noite escura", ressaltando-se a negatividade do epíteto "escura" na sua antítese com luz/vida. Se a "noite" se relaciona com "sono", este é sempre "sono bruto", e o epíteto "bruto" traz carga semântica muito forte, não só pela ausência de conotações suaves e carinhosas, mas porque o seu caráter rude e grosseiro também remete ao estado animal. No sono "bruto", o resquício de "humanidade", que ainda restava em Pedro oprimido e explorado, se desfaz totalmente na morte/animalidade. O projeto ou a aspiração de ser humano e totalmente arrasado. Por isso, nos três primeiros segmentos o verso já se impõe com violência: "Um sono bruto o prostrou", enquanto no quarto segmento a contundência é total: "Um sono bruto anulou".

E agora surge a "serra" da quarta estrofe de cada segmento. Nessa primeira vez, "uma serra muito alta" aparece "Por trás do quarto alugado". O texto ressalta que "Pedro nunca notou" essa serra, como vai ocorrer nos outros segmentos também. A percepção da serra se dá sempre da mesma maneira: "não/Se sabe por quê...", um dia ela é percebida. Importa notar novamente como o enjambement liga a negação, antecipada no final de um verso, com a proposição propriamente dita do verso seguinte, e essa negação é homóloga a toda a defraudação que subjaz ao poema, como à vida de Pedro. Entretanto, Mário de Andrade é posterior (ou contemporâneo) a Freud e a atuação do sub- ou inconsciente, na busca de compensação, se evidencia. O "não/se sabe" não é tão incógnito como afirmado. De 
fato, a percepção da serra, nunca antes notada, sempre ocorre após intensa saturação frustrante, na carência radical de situação opressiva, quando o "dia" com seu "trabalho" esgotou as reservas de energia e resistência, impondo-se a "noite" com seu "sono bruto". Surge então esse lampejo de compensação. Ou então, dentro da rotina massificante do trabalho explorador, surge um instante em que a consciência ilumina tudo: a "serra" existe, mas não é tudo nem o fim último. Além da massacrante rotina do trabalho no dia-a-dia:

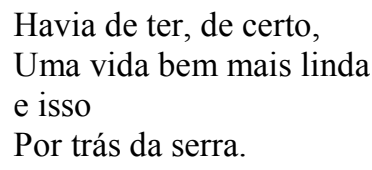

(A serra com seu princípio de possível redenção e no seu caráter distante e mítico, poderia de certa forma indiciar a "aura". Mas o drástico aqui e agora a elimina brutalmente ou vagamente a transfere para o segmento seguinte).

Assim a etapa que se conclui, o "dia" que chega ao seu final, não encerra tudo: abrese uma perspectiva, ainda persiste uma luz. A opressão não acarretou derrota total e o pessimismo não toma conta de tudo. A palavra "vida" se impõe agora em toda sua carga semântica e existencial e se opõe, ainda em antítese, ao simples "vegetar" do restante do segmento. Não consta que Pedro "vive", que ele se realize, que se desenvolva como um "ser humano". Apenas no plano utópico, na compensação puramente aspirada a nível subconsciente, surge a possibilidade de "uma vida bem mais linda". Esse é o "gancho" que permite o prosseguimento, que impulsiona o poema para adiante, para uma outra etapa ou segmento, impedindo que se encerre logo na frustração total da "noite" com seu "sono bruto".

Segundo segmento: Vencida a primeira etapa da história de Pedro, a sua infância no "quarto alugado", com os pais, seu mundo não se fecha totalmente, porque "por trás da serra" certamente "havia de ter" algo melhor: "uma vida". Afinal, a criança ainda nem sequer entrou na "vida"!

\footnotetext{
Sineta que fere ouvido, Vida nova anunciou; Que medo ficar sozinho, Sem pai, mesmo longínquo, sem Mãe, mesmo ralhando, tanta Piazada, ele sem ninguém...

Pedro foi para um cantinho, Escondeu o olho e chorou. Mas depois foi divertido, Alias prazer misturado, Feito de comparação. O menino roupa-nova
} 
Pegava tudo o que a mestra

Dizia, ele não pegou!

Por quê!... Mas depois de muito

Custo, a coisa melhorou.

Ele gostava era da

História natural, os

Bichos, as plantas, os pássaros,

Tudo entrava fácil na

Cabecinha mal penteada,

Tudo Pedro decorou.

Havia de saber tudo!

Se dedicar! descobrir!

Mas já estava bem grandinho

E o pai da escola o tirou.

Ah que dia desgraçado!

E quando a noite chegou,

Como única resposta

Um sono bruto o prostrou.

Por trás da escola de Pedro

Tinha uma serra bem alta

Que o menino nunca olhou;

Logo no dia seguinte

Quando a oficina parou,

Machucado, sujo, exausto,

Pedrinho a escola rondou.

$\mathrm{E}$ eis que de repente, não

Se sabe por quê, Pedrinho

Para a serra se voltou:

- Havia de ter por certo

Outra vida bem mais linda

Por trás da serra! pensou.

Inicia agora a etapa escolar, o caminho de formação para a vida. Surge assim o anúncio de uma "vida nova". Vislumbra-se, pois, a realização da utopia: a "vida" "por trás da serra". (Observe-se que, na "vida" de Pedro só existem fragmentos, estilhaços e ruínas de uma plenitude harmoniosa).

Entretanto, logo a primeira estrofe deste segmento caracteriza negativamente a cena. Primeiramente a "sineta que fere ouvido" interrompe drasticamente a espontânea liberdade do menino. Agora será preciso entrar num universo de silêncio, ordem e disciplina. Essa interrupção da espontaneidade se impõe como contraste, acarretando a imediata solidão com o decorrente medo. O restrito universo tão carente do menino agora se esvazia radicalmente, ficando "sem". Num outro poema da Lira Paulistana Mário extraíra toda a carga possível do advérbio "sem", num verso magistral: "Estou só, estou sem". O advérbio "sem", acompanhado de substantivo ou pronome indica "alguma" limitação ou carência. Mas, desacompanhado como nesse verso, sintetiza a carência e solidão radicais. No poema aqui em análise, o "sem" é menos radical, embora profundamente defraudante. Um verso inicia e termina com o 
advérbio castrante: "Sem pai, mesmo longínquo, sem" - ligando-se por enjambement com "mãe..." Esse verso rompe mesmo a estrutura formal do poema, porque são irredutíveis suas oito sílabas métricas, contrastando com os outros versos de sete sílabas. De certa forma, a suspensão do verso com "sem" cria quase que a mesma sensação do verso do outro poema, em que o "sem" está desacompanhado.

Agora, na escola, o menino está "sem pai, mesmo longínquo" — isto é, o pai sempre andava "longínquo", certamente trabalhando para garantir o sustento - mas o "longínquo" não era "sem", como agora; "sem/Mãe, mesmo ralhando" — o corte, a pausa suspensiva robustece a expressão e o "sem" resulta bem pior do que com a mãe "ralhando"; e finalmente, em meio a "tanta/piazada, ele sem ninguém..." Observe-se ainda o jogo antitético nos finais dos três últimos versos: "Sem"/"tanta"/"ninguém", reforçando o estado psicológico de solidão e carência do menino, como que aturdido pela mudança da relativa harmonia e integração familiar para a estilhaçadora e paradoxal solidão na multidão escolar. (Lembre-se o flâneur mercadoria na multidão baudelaireana).

A segunda estrofe delineia o trajeto psicológico tateante do menino Pedro, do negativo ao positivo, do "chorou" ao "divertido", do "não pegou" ao "melhorou", na lenta integração e aprendizagem. As antíteses persistem, tanto nessa passagem do negativo ao positivo, como, sobretudo, na implícita contrastação de Pedro (no poema narrativo a voz do narrador acompanha a visão focalizadora de Pedro) com o "menino roupa nova". E a sutileza psicológica reforça o contraste social, a inferiorização opressiva de Pedro: "o menino roupanova" e também menino bem alimentado, de inteligência desperta, de orientação adequada portanto com todas as condições favoráveis a boa aprendizagem, ao contrário de Pedro. Mesmo assim, o menino Pedro parece estar a caminho de escalar a "serra" e encontrar "uma vida" do outro lado.

$\mathrm{Na}$ terceira estrofe, o menino descobre seu caminho na escola: o mundo da natureza, a "História natural" — aquilo que lhe estava naturalmente mais próximo "entrava fácil na / Cabecinha mal penteada". Novamente este último elemento metonímico remete condição social do menino, na tendência inferiorizante em que se sente, porque, mesmo na escola disciplinada, esta sua "cabecinha mal penteada", provavelmente distinguindo-o de outros meninos bem trajados e penteados. E insinua-se ainda uma sutileza psicológica, nem sempre pedagogicamente consideradas: Pedro aprende bem a "História natural" — o mundo que lhe é mais familiar, até se entusiasmando pelo assunto: "se dedicar! descobrir!" — provavelmente não lhe interessando assuntos abstratos, distantes, sofisticados, artificiais. E quando o menino 
parecia sentir-se a caminho de ultrapassar a "serra" e encontrar "uma vida" com sentido (sempre uma redenção almejada), "o pai da escola o tirou", porque "já estava bem grandinho". Subjaz à atitude do pai claro indicador cultural ainda hoje tão "normal" no Brasil: criança mais crescida "não precisa" de escola, ou porque ela nada acrescenta a vida, ou porque ela é para gente rica ou, sobretudo, porque o menino precisa ajudar a trabalhar e ganhar o sustento da vida.

Mas a visão do menino Pedro não era esta. E ele, pelo menos no seu íntimo frustrado, reagiu: "Ah que dia desgraçado". Aqui, bem mais do que nos demais segmentos, o "dia" parece mais delineado e definido, restrito a mais curto período temporal. Mas a "noite" que lhe sucede representa ainda bem mais do que o período de descanso pelo trabalho. A "noite" aqui também não tem epíteto. É simplesmente noite, porque ela se abate de repente sobre o itinerário do menino escolar e arrasa suas perspectivas de "uma vida" do outro lado:

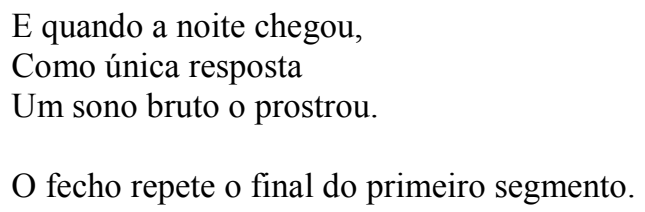

Como essa prostração frustrante da interrupção escolar talvez não fosse julgada suficiente para fazer o menino sonhar com compensação ou com outra "vida" utópica, ele, arrancado da escola, submetido de imediato a um "dia" na oficina, cujo trabalho o deixa "machucado, sujo, exausto". Só após esse "dia" (de abrangência ambígua), "eis que de repente, não / Se sabe por quê" (a aparente ingenuidade prossegue!), surge novamente a "serra":

Por trás da escola de Pedro
Tinha uma serra bem alta
Que o menino nunca olhou.

(A reiterada alucinação "aurática", a redenção possível e defraudada, o "outro", da história, sobrepondo-se à visão do vencedor).

Embora o menino-jovem já esteja no "trabalho" da oficina, a "serra" ainda aparece "por trás da escola", ligada a essa e não a oficina, onde ele já se encontrava. Daí a frustração pela sua retirada forçada da escola.

Parece poder levantar-se uma outra interpretação relativa à "serra", não tão otimista como a anterior. Se a serra foi vista como uma espécie de desafio a ser vencido, na perspectiva otimista de "por trás" encontrar "uma vida", podemos agora interpretá-la também 
de outra maneira: nenhuma etapa encontra um fim pleno em si, nenhum estágio de vida possibilita realização satisfatória a um "paria" como Pedro. A certa altura - e aqui talvez caiba bem a (não) justificativa: "eis que de repente, não / se sabe por que... ", esse estágio ou etapa é interrompido (não permitindo acomodar-se, sentir prazer ou realização nele) porque um novo obstáculo, um novo desafio, uma nova dificuldade ("serra") que antes não havia (no estágio anterior) e por isso não era perceptível, agora se impõe, desacomoda, desafia a resistência de adaptação de quem não foi feito para desfrutar, em definitivo, a "vida" "por trás da serra".

Mas a utopia persiste, o sonho ainda não é vencido. Mesmo que mais outra "serra" exista,

\section{Pedrinho}

Para a serra se voltou:

- Havia de ter por certo

Outra vida bem mais linda

Por trás da serra! pensou.

E entra o SEGMENTO TRÊS ocupando-se de uma "vida de trabalho". O final do segundo segmento já invadiu o tema do terceiro, e não inadequadamente porque, afinal, a "vida" de Pedro, ou o seu "dia" não passa de "trabalho" — apenas interrompido pelo vazio da "noite" (morte provisória) com seu "sono bruto". (Bem pode entender-se como a "mina" ou o império, ao menos passageiro, da "caveira").

Vida que foi de trabalho,

Vida que o dia espalhou,

Adeus, bela natureza,

Adeus, bichos, adeus, flores,

Tudo o rapaz, obrigado

Pela oficina, largou.

Perdeu alguns dentes e antes,

Pouco antes de fazer quinze

Anos, na boca da maquina

Um dedo Pedro deixou.

Mas depois de mês e pico

Ao trabalho ele voltou,

E quando em frente da máquina,

Pensam que teve ódio? Não!

Pedro sentiu alegria!

A máquina era ele! a máquina

Era o que a vida lhe dava!

E Pedro tudo perdoou.

Foi pensando, foi pensando,

E pensou que mais pensou,

Teve uma ideia, veio outra,

Andou falando sozinho,

Não dormiu, fez experiência,

E um ano depois, num grito, 
Louca alegria de amor,

A máquina aperfeiçoou.

O patrão veio amigável

E Pedro galardoou,

Pôs ele noutro trabalho,

Subiu um pouco o ordenado:

- Aperfeiçoe esta máquina,

Caro Pedro! e se afastou.

Era um cacareco de

Máquina! e lá, bem na frente,

Bela, puxa a vida! bela,

A primeira namorada

De Pedro, nas mãos dum outro,

Bela, mais bela que nunca,

Se mexendo trabalhou

$\mathrm{O}$ dia inteiro. Nem bem

A noite negra chegou,

O rapaz desiludido

Um sono bruto prostrou.

Por trás da fábrica havia

Uma serra bem mais baixa

Que Pedro nunca enxergou,

Porém no dia seguinte

Chegando pra trabalhar,

Não se sabe por quê, Pedro

Para a serra se voltou:

- Havia de ter, decerto,

Uma vida bem mais linda

Por trás da serra, pensou.

Se o segmento dois iniciou afirmando que a sineta da escola "Vida nova anunciou" - a palavra "vida" só foi ali empregada, apenas como anúncio e não realidade, e, claro, sempre na referência ao "por trás da serra". (Essa "vida nova" bem pode representar o sempre renovado anseio de "redenção" nessa "morte" que a "história" impõe).

O terceiro segmento inicia com anafórica insistência nessa palavra:

Vida que foi de trabalho,

Vida que o dia espalhou.

Mas, percebe-se evidentemente que essa "vida" não corresponde nem àquela "Vida nova" anunciada pela escola, nem muito menos àquela "vida bem mais linda" que a "serra" intercepta. Aqui a "vida" se resume no "trabalho" e o "dia" espalha, dilui, faz perder o sentido dessa "vida". E a essa anáfora de "vida" defraudada segue imediatamente outra anáfora corroborando a negatividade:

Adeus, bela natureza,

Adeus, bichos, adeus, flores. 
Portanto, dá-se um entrelaçamento dos estágios dois e três. Se o final do segundo interrompeu a escola e antecipou o trabalho "profissional" na oficina, o terceiro centraliza-se no trabalho, mas retoma a situação da escola perdida. Como as situações antitéticas perpassam o poema, poderíamos vislumbrar uma antítese implícita entre os segmentos dois e três. No segundo, a escola representaria um enriquecimento, um caminho para a plenificação na aprendizagem - uma redenção. Mas este se interrompe bruscamente, impondo-se o esvaziamento, a negatividade, a perda acentuada no terceiro segmento: as anáforas "adeus", tudo "largou", "perdeu alguns dentes", um dedo "largou". Essa é, agora, a "vida" de "trabalho" (seria a nova "serra" como que num infindável trabalho de Sísifo? Ou é a reiterada "ruína" que vai apagando as esperanças de redenção?).

Em termos de antíteses, defronta-se outra de relevante importância. Nesse segmento três, Pedro defronta-se com a "máquina", inclusive logo perdendo nela um dedo. Ora, no segmento dois, na escola as afinidades de Pedro eram com a "natureza":

Ele gostava era da

História natural, os

Bichos, as plantas, os pássaros.

(As perdas dos dentes e do dedo indiciam explicitamente a fragmentação, a frustração, a ruína alegórica a que gradativamente vem sendo reduzida toda a "vida" de Pedro).

Mas agora vê-se confrontado com a "máquina", o mecanismo artificial, que o agride imediatamente. Mas, se a antítese se apresenta, ela é imediatamente superada, pois ele não tem ódio a máquina; ao contrário, com ela se identifica:

$$
\begin{aligned}
& \text { A máquina era ele, a máquina } \\
& \text { Era o que a vida lhe dava! } \\
& \text { E Pedro tudo perdoou. }
\end{aligned}
$$

(A máquina, o elemento mecânico-capitalista, representa o novo "senhor" dos novos tempos, reduzindo a ruínas a "vida humana", reduzindo Pedro a simples escravo seu).

O primeiro destes versos exige toda uma ginástica prosódica para reduzir-se a redondilha maior, fato que, aliado a reiteração do vocábulo "máquina", recorrente em mais dois outros versos da estrofe, acentua o confronto "harmonioso" do menino-moço de vida "natural" com a indústria mecânica.

Parece impor-se uma conclusão: por mais que a "vida" e o "trabalho" sejam frustrantemente opressivos, Pedro mantém uma atitude de abertura, de perdão, de 
adaptabilidade máxima. Denotaria isso alienação, entrega ingênua ao explorador? Ou residiria nessa atitude o cerne do "pathos" trágico, tão forte na orientação social do poema?

A segunda estrofe deste segmento bem evidencia essa identificação de Pedro com o engenho tecnológico, quase que esquecendo-se de si mesmo para conviver com a máquina que logra aperfeiçoar. O relacionamento do patrão com ele, "explorando" sua disposição, manifesta-se patente ao separá-lo dessa máquina para que aperfeiçoe também outra. (Daí claramente poder associar-se o alegórico com a melancolia!)

Sutilmente, então, a frustração se impõe na terceira estrofe: separado da "sua" máquina - "A primeira namorada", quatro vezes qualificada de "bela" — e encarregado agora de "um cacareco de / máquina", a submissa aquiescência ao patrão, não expandindo ou explodindo exteriormente a interior reação frustrante, conduz "noite/sono"/morte provisória:

Nem bem
A noite negra chegou,
O rapaz desiludido
Um sono bruto prostrou.

(Como seria possível vislumbrar nessa frustração fragmentadora intermitente o menor indício duma harmonia totalizadora e orgânica a caracterizar o símbolo clássico?)

E como a "fábrica" não é caminho de realização final, como, por mais que se esforce e produza bons resultados no aperfeiçoamento de uma máquina, não há estabilização numa carreira que proporciona realização pessoal no trabalho, novamente surge a "serra", agora "por trás da fabrica", embora seja "bem mais baixa". Antes "Pedro nunca enxergou", ou seja, ela não existia para ele enquanto punha toda sua atenção e todo o seu ideal no trabalho que até o satisfazia. Por que essa nova interceptação é "bem mais baixa"? Seria por que o novo obstáculo não é tão radical: aperfeiçoada uma máquina, não seria tão difícil aperfeiçoar outra? Ou seria por "sabedoria" do mecanismo psicológico: as sucessivas frustrações desgastam as energias e estas, sendo menores, projetam obstáculo menor, pois como enfrentariam ainda uma "serra bem alta"? Seja como for, a utopia persiste, vislumbrando "uma vida bem mais linda / Por trás da serra, pensou." (A "história" não é retilínea, homogênea e vazia mas, como vê o "Anjo da História" (Tese IX), "uma catástrofe que sem cessar acumula escombros sobre escombros, arremessando-os diante dos seus pés").

E o quarto segmento vai retratar a vida familiar e a morada nova.

Oh, segunda namorada, Flor de abril! cabelo crespo,

Mão de princesa, corpinho 
De vaca nova... Era vaca.

Aquele riso que faz

Que ri, nunca me enganou...

Caiu nos braços de quem?

Caiu nos braços de todos,

Caiu na vida e acabou.

Com a terceira namorada,

Na primeira roupa preta,

Pedro de preto casou,

E logo vieram os filhos,

Vieram doenças... Veio a vida

Que tudo, tudo aplainou.

Nada de horrível, não pensem,

Nenhuma desgraça ilustre

Nem dores maravilhosas,

Dessas que orgulham a gente,

Fazendo cegos vaidosos,

Tísicos excepcionais,

Ou formando Aleijadinhos,

Beethovens e heróis assim:

Pedro apenas trabalhou.

Ganhou mais, foi subindinho,

Um pão de terra comprou.

Um pão apenas, três quartos

E cozinha, num subúrbio

Que tudo dificultou.

Menos tempo, mais despesa,

Terra fraca, alguma pêra,

Emprego lá na cidade,

Escola pra filho, ofício

Pra filho, um num choque de

Trem, inválido ficou.

— Sono! único bem da vida!...

Foi essa frase sem forca,

Sem história natural,

Sem máquina, sem patente

De invenção, que por derradeiro

Pedro na vida inventou.

E quando remoendo a frase,

A noite preta chegou,

Pedro, Pedrinho, José,

Francisco, e nunca Alcibíades,

Um sono bruto anulou.

Por trás da morada nova

Não tinha serra nenhuma,

Nem morro tinha, era um plano

Devastado e sem valor,

Mas um dia desses, sempre

Igual ao que ontem passou,

Pedro, João, Manduca, não

Se sabe por quê, Antônio,

Para o plano se voltou:

- Talvez houvesse, quem sabe,

Uma vida bem mais calma

Além do plano, pensou. 
A ligação do quarto com o terceiro segmento se processa através das "namoradas". A "primeira namorada" de Pedro fora a máquina aperfeiçoada. Ela o frustrou porque lhe foi arrebatada, cabendo-lhe em troca "um cacareco de máquina". O quarto segmento inicia aludindo a "segunda namorada", ambiguamente configurada na mulher "de todos", talvez até ilusória esperança na ingenuidade de Pedro.

Mas surge a "terceira namorada", mais estável, não compensadora das contrariedades e frustrações da "vida". Não é simples referência de etiqueta a insistência na cor:

\section{Com a terceira namorada,}

Na primeira roupa preta,

Pedro de preto casou.

O "preto" já vem anunciado com insistência, no término de cada etapa da vida, pelo binômio "noite/sono", qualificado por epítetos explicitadores da orientação semântica negativa: "noite escura", "noite negra" e o infalível "sono bruto" que prostra. Mas se a "negra" asa da noite/sono/morte/frustração se entremostrava no final dos estágios-segmentos anteriores, agora o "preto" já se antecipa quase no início do segmento e no contexto do casamento, conotando implícitas antíteses. Poderia, na mesma orientação semântica, a "roupa preta" da "namorada" indicar luto de viuvez dela e, portanto, não mais sendo "virgem" ou "original" ou "unicamente" dele.

E os versos prosseguem explicitando a confirmação dos negros augúrios no peso dos filhos, nas doenças, na rotina quase que tudo nivelando. Se a deficiência, a carência, a defraudação persistem, até mesmo o paradoxo da deficiência compensada não lhe é permitido. Daí:

Nenhuma desgraça ilustre

Nem dores maravilhosas...

Ou então:

Aleijadinhos sem dedos mas escultores hábeis ou Beethovens surdos mas gênios musicais.

Nenhum heroísmo é permitido a Pedro - porque a Modernidade, segundo Baudelaire, não comporta mais heróis.

No caso de Pedro, apenas "Veio a vida / Que tudo tudo aplainou." Ou seja: "Pedro apenas trabalhou" no raso da vida, na rotina niveladora, sem nunca transpor "serra" alguma, sem atingir compensações, mesmo que fossem paradoxais. E verdade que, com a persistência no trabalho, até 
Ganhou mais, foi subindinho,

Um pão de terra comprou.

Observe-se a expressividade angustiante desse gerúndio em diminutivo, achado criativo que conota um amálgama de afetividade, persistência e radical consciência de limitação. As forças gradativamente se esgotam, as resistências se esvaem. Abatido, defraudado, desiludido, esgotado pela exploração da "vida" e pelo "trabalho" sem compensação, Pedro atinge o ápice, não da "serra" para deslumbrar-se com "uma vida bem mais linda" para além dela, mas do abatimento e frustração, numa síntese do trajeto percorrido:

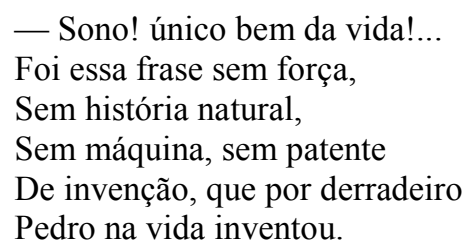

Novamente a insistência no defraudante "sem" carrega negativamente a situação toda. E nessa carência total, a definitiva "noite preta chegou" (preto com preto, desde o início do segmento) e

\author{
Pedro, Pedrinho, José, \\ Francisco, e nunca Alcibíades, \\ Um sono bruto anulou.
}

Essa não é, portanto, a "sorte" apenas de Pedro, mas de muitos, do comum dos homens, de que escapa apenas "Alcibíades"— isto é, se há o sofrido, o explorado e frustrado, deve haver também o outro lado, não existindo o causado sem a causa. (Claramente aqui o poema faz referencia a história dos vencedores e opressores, uns poucos a sugarem o sangue da maioria, que constituem, como Pedro, o "outro" da história que não aconteceu). Então, com essa terceira estrofe do quarto segmento, desaparece a visão "com" a personagem, assumindo o cantador-narrador a voz e a visão, embora de certo modo até a visão "com" Pedro persistisse na coletividade dos seus semelhantes.

Entretanto, Pedro não é só Pedro, como já visto. É ele e o "outro", ele e os outros, ele e muitos outros. Por isso, mesmo após fixar-se ele no raso horizontal pós-morte, ambiguamente a utopia prossegue (com ele e seus iguais no destino). Por uma parte, não há mais interceptação que desafia, porque não há mais possibilidade de passagem, como não há mais força a ser dispendida em esforço. Então: 
Não tinha serra nenhuma,

Nem morro tinha, era um plano

Devastado e sem valor.

(Poder-se-ia constatar aqui a aniquilação de qualquer perspectiva de redenção, de ideal, de transcendência, impondo-se a "história natural", a ruína, caveira e morte definitivas, sem abertura nenhuma).

Ainda assim o definitivo dessa planície da noite negra não é o fim final. Porque o ciclo prossegue, uma vez que Pedro é também o "outro" e muitos outros. E a vaga utopia, frágil e trêmula ("talvez", "quem sabe") ainda não se apagou de todo — nesse dia igual ao de sempre, para ele e para os outros:
Mas um dia desses, sempre Igual ao que ontem passou, Pedro, João, Manduca, não Se sabe por quê, Antônio, Para o plano se voltou:

E os três versos finais agora diferem das vezes anteriores, muito vagos:

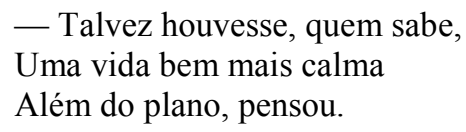

Confronte-se com a forma das vezes anteriores:

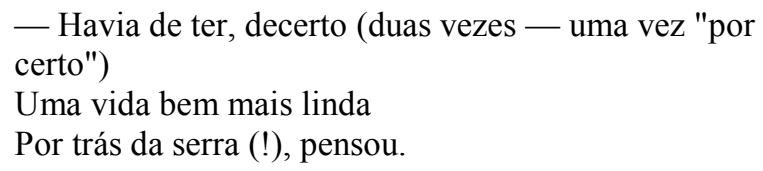

A quase certeza, confiante e otimista, substitui-se por uma vaga possibilidade, muito incerta; a vida "linda" cede para uma vida apenas "calma"; "por trás da serra" (parece lugar bem mais definido) substitui-se por também vago lugar: "Além do plano".

Epílogo: Nas três pequenas estrofes que alteram agora a simetria estrutural do poema, constituindo o epílogo, o narrador-cantador assume participativamente a causa de Pedro e de seus "outros", amarrando os fios prenunciadores durante o poema:

Havia, Pedro, era a morte, Era a noite mais escura, Era o grande sono imenso; 
Decepa, assim, o narrador qualquer possível ramo de esperança, de saída, de redenção, pondo fim em definitivo à insistente utopia. A defraudação foi total, a luta trabalhosa foi de todo infrutífera. E a essa altura o próprio cantador-narrador não se contém, irrompendo em violências imprecatórias, mesmo contra o desgraçado que não reagiu, que se deixou usar e explorar, que colaborou em certo estado de alienação:

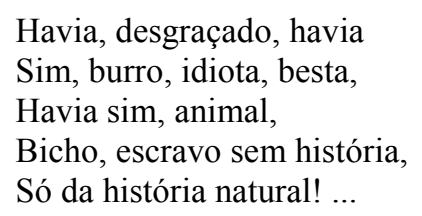

(Essa reação violenta e agressiva do cantador-narrador diverge claramente da "melancolia" do Benjamin alegórico, para quem até no "Anjo da história" (Tese IX) as "asas estão prontas para voar", porque "ele bem que gostaria de poder parar, de acordar os mortos e de reconstruir o destruído. Mas uma tempestade sopra do Paraíso" — isto é, após a queda e expulsão, a história se reduz a fragmentos, cacos, minas, nas mãos dos vencedores-opressores, sem o menor equilíbrio harmônico).

A última estrofe, laconicamente, esclarece a generalização dessa "história muito triste" de Pedro, que não é só Pedro, mas também o "outro" e muitos outros que terminam no mesmo implacável raso horizontal de que não lograram sair em momento algum da vida, porque a "serra" nunca lhes permitiu encontrar (ou construir) uma "vida" "por trás" dela:

Por trás do túmulo dele

Tinha outro túmulo... Igual.

É a pá de cal final sobre qualquer ilusão de toda uma classe, numa violenta denúncia social desse "poeta político" que foi o último Mário de Andrade, evidenciando a história como "uma catástrofe única", dentro da qual é bem mais evidente a fragmentação alegórica do que o simbolismo orgânico.

\section{Perspectivas conclusivas sobre o poema}

Definir agora o caráter simbólico ou alegórico deste poema não é tarefa tão simples. Parece poder-se perceber uma tendência mais simbólica na poesia intimista de Mário de Andrade, nos poemas mais diretamente líricos, nos poemas em que Mário busca e analisa a identidade problemática, a expressão difícil de um "eu" em crise, sempre de novo caracterizando a fragmentação do "eu". Nesse sentido, com parâmetros psicanalíticos, João 
Luiz Lafetá procede a um minucioso levantamento das "imagens na poesia de Mário de Andrade", no livro Figuração da Intimidade, detectando muitos símbolos nos poemas que analisa, parte apenas pequena da obra poética total.

Mas na sua poesia mais social, na produção do "poeta político", talvez não seja o símbolo, mas a alegoria que ganha espaço. O poema narrativo "Agora eu quero cantar" não trata, como vimos, dos estados emotivos de um "eu" interior, mas conta uma "estória", cuja tendência se inclina claramente ao enfoque de problemática social na época industrialcapitalista.

Já nessa perspectiva, segundo observa Mário F. Bolognesi (1989:30), em sua dissertação sobre a peça Vladimir Maiakovski:uma tragédia, as próprias condições sóciohistóricas da época não correspondem às características de harmonia e totalidade próprias do símbolo: "O desenvolvimento do capitalismo e a realidade do sofrimento, da fragmentação e da ruína desfiguravam aquela totalidade do símbolo e a harmonia do mundo. $O$ sujeito clássico, no século XX, está morto. Na época contemporânea objeto e homem sofrem um processo de desintegração". Essa desfiguração e fragmentação, a redução do trabalhador a mercadoria com seu valor de troca, a divisão de classes sociais pelo capitalismo - tudo conduz a fragmentação e ruína, muito mais próximas do caráter alegórico do que simbólico.

Sem dúvida, o poema de Mário de Andrade não se reduz a uma simples história de um cantador, despretenciosa e inocente, cantada para diversão e distração dos ouvintes ou leitores. O sentido subjacente é bem mais amplo e denso, os próprios elementos sensíveis Pedro, suas fases de vida, o trabalho, o dia, a noite, o sono, a serra, etc. — não esgotam a significação em si mesmos, remetendo inegavelmente a algo mais, a um "outro" polissêmico. Mas contrapor um particular a um universal (Schelling, Goethe), quer no sentido de o particular apenas significar o universal, que é intuído por meio do particular, transitivamente, mudando-se o fenômeno em conceito, para exprimir o dizível, quer no sentido de o particular ser o universal, constituindo os dois um único absoluto, na intransitividade que sugere o indizível - tal contraposição não se aplica facilmente ao poema de Mário de Andrade.

Talvez o método de trabalho de Benjamin possa ser mais conveniente. Numa passagem da Origem do Drama Barroco Alemão (1984, p.188) escreve Benjamin:

A relação entre o símbolo e a alegoria pode ser compreendida, de forma persuasiva e esquemática, à luz da decisiva categoria do tempo, que esses pensadores da época romântica tiveram o mérito de introduzir na esfera da semiótica. Ao passo que no símbolo, com a transfiguração do declínio, o rosto metamorfoseado da natureza se revela fugazmente à luz da salvação, a alegoria mostra ao observador a facies hippocratica da história como proto-paisagem petrificada. A história em tudo o que nela desde o início é prematuro, 
sofrido e malogrado, se exprime num rosto - não, numa caveira. E porque não existe, nela, nenhuma liberdade simbólica de expressão, nenhuma harmonia clássica da forma, em suma, nada de humano, essa figura, de todas a mais sujeita à natureza, exprime, não somente a existência humana em geral, mas, de modo altamente expressivo, e sob a forma de um enigma, a história biográfica de um indivíduo. Nisso consiste o cerne da visão alegórica: a exposição barroca, mundana, da história mundial do sofrimento, significativa apenas nos episódios do declínio.

Aqui a alegoria está ligada por Benjamin a "história" e essa história-destino configurada na "caveira", isto é, ordenando-se em torno da figura da morte. Assim, a alegoria, em Benjamin, retrata o mundo em ruína e fragmentação temporal, a vida a partir da morte, ou a morte existente na vida, ao contrário da harmonia e totalidade próprias do símbolo clássicoromântico. A alegoria é, assim, a ruína do que não houve, do "outro" que não houve, das possibilidades ou potencialidades que poderiam ter sido, mas não aconteceram.

Em certo sentido, não será isso que se faz presente no poema de Mário? Se na própria etimologia a alegoria — "allos" + "agoreuein" — significa dizer "o outro" e se, para Benjamin, essa forma de "dizer o outro" indicia perda, "ruína", "caveira", enfim, morte, história do malogro e sofrimento, esse "outro" que está por trás dos elementos sensíveis do poema "Agora eu quero cantar" se aproxima muito dessa perda, ruína e morte destacados por Benjamin. Pedro não é (apenas) um determinado indivíduo (histórico), mas antes essa individualidade concreta se esvazia para remeter a uma generalidade bem mais ampla (Hegel) do trabalhador na massificante e exploradora engrenagem industrial-capitalista. Claramente o próprio texto insinua que Pedro (e sua condição) é também (a condição de) Pedrinho, José, Francisco, ou então João, Manduca, Antonio - isto é, os muitos "outros" de destino igual ao seu, "ruínas" ou projetos não realizados, potencialidades defraudadas, carregando a morte na vida.

Opostamente, Pedro não pode ser nunca Alcibíades, como seus pais também não cogitaram em chamá-lo Floriscópio, Ciro, Adrasto - nomes esdrúxulos, sofisticados, de etimologias ou filiações históricas mais nobres, que, por sua vez, são "outros" numa certa generalidade de nível diverso (na classe econômico-social, na dimensão dos dominadoresexploradores que fizeram escrever a história na sua perspectiva).

Pedro e seus "outros" se reduzem a fragmentações no seu frustrante trajeto existencial, e para Benjamin (1984, p. 208) "é sob a forma de fragmentos que as coisas olham o mundo, através da estrutura alegórica".

Componentes metonímicos, ou talvez sinedóquicos, dessa fragmentação constituem as etapas de Pedro na casa paterna, na escola, na fábrica, na família constituída e na "morada nova", bem como o trabalho, o dia, a noite-sono, a serra. Cada qual desses elementos, por sua 
vez, não tem significação fechada, mas comporta um "excesso de significação" que Ricoeur (1987, p. 66 ss.) caracteriza como símbolo, mas que, entretanto, não passam de estilhaços duma fragmentação que destrói a unidade orgânica. Assim, o "dia" não é denotativamente o período determinado pela rotação da terra, mas, no poema, indica uma fase maior e pode aludir à própria "vida". A "noite" com o "sono bruto" igualmente não corresponde apenas ao oposto de "dia" — período claro com sol e período escuro sem sol. Além de conotar a necessidade de descanso na exaustão, período de repouso e transição para outra fase, o binômio "noite/sono" traz em seu "excesso de significação" a ideia de morte. E a "serra" praticamente nada conserva de seu sentido denotativo, geográfico-topológico, de elevação montanhosa, mas aponta polissemicamente para o obstáculo, a dificuldade, a barreira interceptativa ou a escalada íngreme a ser transposta para chegar ao outro lado.

Se Flávio R. Kothe (1986, p. 52-53) insiste no aspecto ideológico da alegoria, no abuso de sua interpretação a partir do poder dominante, poder-se-ia talvez ver no poema de Mário de Andrade uma alegoria da relação trabalhador-máquina na modernidade, a partir do dominado. Ao contrário de uma alegoria glorificante do trabalhador, como se daria por exemplo no regime socialista soviético pós-revolução de 1917; ao contrário duma alegoria glorificante da máquina/industrialização num regime capitalista, temos aqui algo parecido, embora mais deprimentemente trágico, com o que Chaplin apresenta no filme Tempos Modernos. Não há glorificação do progresso, da industrialização, numa visão idealizada do operário construtor do bem-estar social. Ao contrário, a modernidade e a industrialização aparecem retratadas a partir de baixo, com seus reflexos deprimentes, opressores sobre o trabalhador explorado. Daí insistir Benjamin na necessidade de considerar-se o outro lado da história: o daquela massa de oprimidos, da "anônima servidão" que foi pilhada para acumularem-se os "bens culturais" que constituem o "progresso", sempre expostas à condição de "sujeitar-se a ser um instrumento da classe dominante". História não é conformismo, pois o Messias não vem apenas como Salvador, ele vem como o vencedor do Anticristo" (Tese VI).

Para Benjamin (1984, p. 240 ss) a caveira e a esfinge da morte dominam, e não sem sentido, no drama barroco: "Se os personagens do drama barroco morrem, é porque somente assim, como cadáveres, têm acesso a pátria da alegoria". Essa insinuação da morte na vida, que Benjamin bem destaca na alegoria, manifesta-se nitidamente no poema-estória em apreço. Não é por acaso que o poeta-cantor, já na primeira estrofe, se propõe a cantar. 
O "acabou", já com o travo da morte, precede o "principiou". Periodicamente, no poema da história de Pedro,

\title{
Um sono bruto o prostrou.
}

reduzindo-o provisoriamente à morte. Da escola, o pai o tirou cedo, para não ter a devida iniciação à vida. Forçado ao trabalho na oficina,

\author{
Perdeu alguns dentes e antes, \\ Pouco antes de fazer quinze \\ Anos, na boca da maquina \\ Um dedo Pedro deixou.
}

São fragmentações que se processam, lascas que a morte vai arrancando em vida da personagem, bem na linha do alegórico.

Quando ele aperfeiçoa uma máquina e nela vê sua "primeira namorada", esta lhe é arrebatada e recebe em troca "um cacareco de máquina", como a ele próprio os elementos positivos vão sendo arrancados, reduzindo-o a um "cacareco". A "segunda namorada", também se reduz a fragmentação total, pois

\section{Caiu nos bravos de todos, Caiu na vida e acabou.}

Depois um filho "num choque de / Trem inválido ficou". Os fragmentos são arrancados do seu contexto e tornam-se signos à espera da significação alegórica.

Se Benjamin (1984, p. 211) aplica à alegoria traços da tragédia grega, o poema em torno de Pedro sintetiza uma tragédia, que não apenas individual mas múltipla, coletiva, de intensas dimensões sociais, estando disseminados indícios trágicos desde o início.

Fredric Jameson (1985, p. 62), analisando a contribuição de Benjamin, tenta precisar: "a distinção entre símbolo e alegoria é a que existe entre total reconciliação entre objeto e espírito e um mero desejo de tal reconciliação". Se no aspecto temporal, "o símbolo e o momento no tempo, instantâneo, lírico, único", já a alegoria "é o modo privilegiado de nossa própria vida no tempo, um canhestro decifrar de significado de momento a momento, uma penosa tentativa de restaurar uma continuidade em instantes heterogêneos e desconexos". Esse "canhestro decifrar", essa "penosa tentativa" parecem estar exemplificados no retratotrajetória de Pedro, feito por Mário de Andrade.

No poema, pode-se perceber como, segundo Jameson (1985, p. 66) "os fragmentos estilhaçados da alegoria representam um mundo-coisa de forças destrutivas no qual a autonomia humana soçobra". O poema também denuncia como "o outro da alegoria é o outro 
reprimido" (KOTHE, 1976, p. 37). Resulta assim o poema todo, na sua dimensão social, como uma alegoria anti-glorificadora da vida moderna e da interação trabalhador-máquina, até mesmo uma heroicidade às avessas. Não foi, pois, sem razão, que Naief Sáfady, no "estudo crítico" sobre Mário de Andrade, na serie Poetas do modernismo (vol. I, 1972, p. 103), editada por Leodegário de Azevedo Filho, coloca o poema "Agora eu quero cantar" como "irmão maior do 'sem caráter' Macunaíma e prima (sic) do José, de Carlos Drummond, do Riobaldo, de Guimardes Rosa".

Embora "Agora quero cantar" seja um poema narrativo, pertencendo ao âmbito ficcional e não histórico, parece ele, na perspectiva possível dentro do seu gênero, corresponder a concepção que Benjamin (sobretudo nas "Teses", 1985) defendia para a história materialista. Evitando o perigo constantemente ameaçador de "sujeitar-se a ser um instrumento de classe dominante" (Tese VI) e de identificar-se com o vencedor (Tese VII), conforme era praxe no historicismo, o narrador, ou melhor, o condutor do foco narrativo deste poema integra a classe dos dominados, vencidos e explorados na história, bem evidenciando o acúmulo de sofrimentos e privações a que esta sujeita a maior parte da humanidade, a fim de possibilitar o desenvolvimento dos "bens culturais". Aqui, o narrador-autor parece identificarse com o "Anjo da História" (Tese IX), de olhos arregalados, de boca aberta e de "rosto voltado para o passado" (embora a miséria de Pedro não lhe possibilite tanta consciência!), vendo "uma catástrofe única, que sem cessar acumula escombro sobre escombro", porque a "tempestade" do "progresso" impele tudo para diante, manipulada pelos vencedoresopressores da história, extorquindo tudo dos dominados, a cujo sangue a história triunfa, na linha da concepção corrompida e positivista do trabalho, ao contrário daquela defendida por Benjamin, com Fourier, de proporcionar "condições de gerar as criaturas que potencialmente dormitam em seu seio" (Tese XI).

Mário de Andrade parece concordar, em seu poema, com a posição de Benjamin de que "o sujeito do conhecimento histórico é a própria classe oprimida em luta" (Tese XII), denunciando ambos como "A concepção de progresso do gênero humano ao longo da história é algo inseparável da concepção de que esta transcorra num tempo homogêneo e vazio" (Tese XIII), ao passo que "A história objeto de uma construção, que tem lugar não no tempo vazio e homogêneo, mas no repleto de atualidade" (Tese XIV). Cada geração carrega consigo "uma fraca força messiânica", sendo que todo "o passado arrasta consigo um índice secreto que o remete a salvação" (Tese II), pelo que "nada do que alguma vez tenha acontecido pode ser considerado perdido para a história" (Tese III). Cabe, assim, ao historiador materialista (e por 
que não igualmente ao ficcionista consciente da realidade do seu momento histórico?) reconhecer numa "constelação saturada de tensões" "o signo de uma paralisação messiânica dos acontecimentos, ou seja, o signo de uma chance revolucionária na luta pelo passado oprimido" (Tese XVII).

Assim, dentro da lógica da fragmentação alegórica em que pode ser lido o poema de Mário de Andrade, destrocando-se o indivíduo na engrenagem tecnológico-capitalista, evidencia-se também, denunciada pelo próprio foco narrativo, "a facies hippocrita da história", uma história em que, ressalta Benjamin (1984, p. 188), não existe "nenhuma liberdade simbólica de reflexão, nenhuma harmonia clássica da forma, em suma, nada de humano", ou seja, "a história como história mundial do sofrimento". Desvela, então, o narrador-autor a outra face da história, o "outro" da história, aquilo que poderia ter sido mas não teve condições de tornar-se, como todos os anseios e sonhos de Pedro esboroaram-se no "sono bruto", embora persistisse sempre, bem expresso no "símbolo" da "serra", aquela "fraca força messiânica", sempre de novo supressa pelo condutor-dominador-explorador que acaba fazendo a história como que sua (embora aparentemente nunca seja visível ou esteja exposto). Vigorosa é a denúncia do poeta Mário de Andrade, em perfeita correspondência com o crítico Mário de Andrade, conforme define a epígrafe.

Também poder-se-ia examinar o poema em causa na perspectiva da concepção benjamineana da aura. Embora não exatamente em relação ao poema-objeto-de-arte, mas antes em relação ao enfoque geral do tema trabalhador-máquina-trabalho, não parece absurdo falar-se aqui em deterioração da aura. Nem Pedro, nem a máquina, nem situação alguma da sua vida parecem reservar a mínima condição da aura, como algo distante, misterioso, sagrado. Se o homem-trabalhador-Pedro como que se objetifica em vítima autômata do "destino" capitalista do "progresso", poder-se-ia esperar uma glorificação aurática do instrumento tecnológico, da máquina, mas até o rude e desvalorizado Pedro (ainda que alimente um certo respeito e amizade auráticos para com a máquina-namorada) logra aperfeiçoá-la, destituindo-a assim de qualquer "veneração" distante e misteriosa. Apenas a "serra" conserva até certo ponto uma espécie de caráter distante, sagrado e único, escapando sempre de novo da aproximação e apropriação, embora se desvaneça na ilusão para Pedro. Essa constante desauratização, essa desmistificação de tudo o que se relaciona com a mísera condição do trabalhador Pedro encaminha ainda para a confirmação da linha alegórica do poema, longe do "sublime" símbolo. 
$\mathrm{Na}$ linha da modernidade, Mário de Andrade, também neste poema, tem afinidade com o caminho aberto por Baudelaire. Tematiza, por exemplo, a heroicidade da vida privada, numa heroicidade às avessas, pois essa "heroicidade" enfatiza a figura marginal, o indivíduo massificado no social, um quase "lixo da sociedade". Se Mário não chega ao "catador de trapos", seu anti-herói acaba mais objeto que sujeito, na engrenagem industrial urbana. E o poeta, sem dúvida, um artista imerso no mundo, um observador do cotidiano nas dimensões mais vulgares, registrando o transitório e efêmero, o anti-sublime, a que restitui valorização.

[Este artigo teve sua primeira publicação no n. 1, 1993, da Anuário de Literatura]

\section{Referências}

BENJAMIN, Walter. Origem do drama barroco alemão. São Paulo: Brasiliense, 1984.

BOLOGNESI, Mário Fernando. "Tragédia: uma alegoria da alienação". In.: Transformação. São Paulo, nº 12, p. 23-36, 1989.

JAMESON, Fredric. Marxismo e forma: Teorias dialéticas da literatura no século XX. São Paulo: Hucitec, 1985.

KOTHE, Flavio R. A alegoria. São Paulo: Áttica, 1986. . Para ler Benjamin. Rio de Janeiro: Francisco Alves, 1976.

LAFETÁ, Joao Luiz. Figuração da intimidade: Imagens na poesia de Mário de Andrade. São Paulo: Martins Fontes, 1986.

NUNES, Benedito. "Mário de Andrade: as enfibraturas do Modernismo". In.: Revista Iberoamericana $\mathrm{n}^{\circ} 125$, p. 63-75, Ene-Mar. 1984.

Ricoeur, Paul. Teoria da Interpretação. Lisboa: Edições 70, 1987.

SÁFADY, Naief. "Mário de Andrade: Estudo crítico". In.: AZEVEDO FILHO, Leodegário A. de (ed.). Poetas do Modernismo. Rio de Janeiro: Instituto Nacional do Livro, 1972.

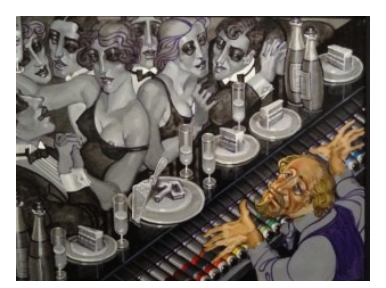

